\title{
Lichens as Indicators of the Urban Environment Quality
}

\author{
Istomina N.B., Likhacheva O.V. \\ Pskov State University, Pskov, Russia \\ e-mail: pskov.pgpu.bot@mail.ru
}

\begin{abstract}
The ranging of lichens among classes of poleotolerance were made. The most widely spread species from each class are mentioned. The estimation of the ecological state of air environment of the city of Pskov with lichens was held.
\end{abstract}

Keywords - lichenoindication, lichens, sensitive and tolerant species.

\section{INTRODUCTION}

In the system of the urban environmental quality assessment lichens are widely used as indicators of air pollution. The most common methods are air quality mapping, determination of the projective cover of epiphytic lichens, investigation of the biology of lichen species tolerant and sensitive to the air pollution. There are data of ecological state of a number of Russian cities such as Moscow [2], SaintPetersburg [3], Yoshkar-Ola [7], Yekaterinburg [5], Kazan’ [1], Krasnodar [6], etc.

\section{MATERIALS AND METHODS}

During the lichenological research in the city of Pskov 121 lichen species were identified there $[4 ; 9]$. Ranging of lichen species according to the scale of poleotolerance proposed by H. Trass [8] was made. Most lichen species react to different pollutants of urban environment [2]. The proposed 10-point scale helps to determine the level of air pollution of study area on the analysis of the lichen species composition.

\section{RESULTS AND DISCUSSION}

As a result, the species belonging to 7 classes of poleotolerance (from 10) were found in the city. There are no representatives from the first two classes, which include highly sensitive to pollution lichens confined to anthropogenically undisturbed habitats.

Species of the third, fourth and fifth classes, spreading in the natural or slightly to moderately disturbed habitats, are confined to forest ecosystems (forest parks), located on the outskirts of the city, and to the parks in the central part of it. Among them are Hypogymnia tubulosa (Schaer.) Hav., Tuckermanopsis chlorophylla (Willd.) Hale, Usnea subfloridana Stirt. (Class 3), Graphis scripta (L.) Ach., Lecanora leptyrodes (Nyl.) Degel, Melanelixia subaurifera (Nyl.) Essl., Pseudevernia furfuracea (L.) Zopf, Vulpicida pinastri (Scop.) J.-E. Mattsson et M. J. Lai (Class 4), Lecanora argentata (Ach.) Malme, Lecidella euphoria (Flörke) Hertel, Physcia aipolia
(Ehrh. ex Humb.) Furnr., Lecania cyrtella (Ach.) Th. Fr., Ramalina farinacea (L.) Ach. (Class 5), etc.

The most common species for the green areas of the city (parks, squares, plantings along the streets, neighborhood territories, etc.) are tolerant taxa related to the 7-9th classes. The presence and high frequency of these groups of lichens shows a strong anthropogenic change in the habitats. There are such species as, Candelariella vitellina (Hoffm.) Müll. Arg., C. xanthostigma (Ach.) Lettau, Phaeophyscia nigricans (Flörke) Moberg, Physcia adscendens $\mathrm{H}$. Oliver (Class 7), Physconia enteroxantha (Nyl.) Poelt, Caloplaca cerina (Ehrh. ex Hedw.) Th. Fr., Xanthoria candelaria (L.) Th. Fr. (Class 8), Phaeophyscia orbicularis (Neck.) Moberg, Xanthoria parietina (L.) Th. Fr. (Class 9), etc. These lichens are most often found in urban areas.

Species relative to the $10^{\text {th }}$ class of poleotolerance, such as Scoliciosporum chlorococcum (Graewe ex Stenh.) Vězda, Lecanora hagenii (Ach.) Ach., Lepraria incana (L.) Ach., are confined in their distribution to habitats along the highways with active transport movement. The high frequency of these species indicates a very strong anthropogenic disturbances.

\section{CONCLUSIONS}

Thus, the territory of the city of Pskov can be described as moderately polluted. As the distance from the center to the periphery, where the recreational, forest park areas are located, extends the number of species confined to the natural and slightly disturbed habitats and sensitive to air pollution increases. But in the central part of the city such green areas as parks and gardens appear to be a kind of refugium for a number of lichens relative to natural and undisturbed habitats.

\section{REFERENCES}

[1] Baibakov E.I. Assessment of the environmental condition of urban areas using methods of lichen indication (by the example of Kazan'). Synopsis of a thesis. Izhevsk, 2003, 19 pp. [In Russian] 
[2] Byazrov L.G. Lichens in the environmental monitoring. Moscow, 2002, 336 pp. [In Russian]

[4] Malysheva N.V. Lichens of the city of Pskov. 1. Brief analysis of lichen flora. Botanical journal. 2004. Vol. 89. №7, pp. 1070-1077. [In Russian]

[5] Paukov A.G. Lichen flora of urban ecosystems. Synopsis of the thesis. Yekaterinburg, 2001, 18 pp. [In Russian]

[6] Sionova N.A. Assessment of the ecological state of the atmospheric environment in the city of Krasnodar by the methods of lichenoindication. Synopsis of the thesis. Krasnodar, 2006, 20 pp. [In Russian]

[7] Suetina Y.G. Changes in epiphytic lichen flora and Xanthoria parietina (L.) Th. Fr. population structure in an urban
[3] Malysheva N.V. Lichens of Saint-Petersburg. SaintPetersburg, 2003, 100 pp. [In Russian]

environment. Synopsis of the thesis. Yoshkar-Ola, 1999, 26 pp. [In Russian]

[8] Trass H.H. Classes of poleotolerance of lichens and environmental monitoring. Problems of ecological monitoring and modeling of ecosystems. Leningrad, 1985. Vol. 7. pp. 122-137. [In Russian]

[9] Environmental monitoring of the urban area with the bioindication methods (by the example of the city of Pskov. Part 1. Pskov, 2009, 188 pp. [In Russian] 